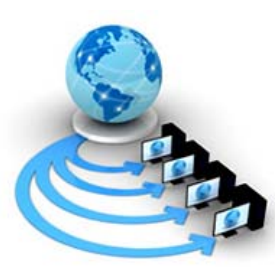

Volume 8, No. 9, November-December 2017

International Journal of Advanced Research in Computer Science

RESEARCH PAPER

\title{
DEVELOPMENT MOBILE APPLICATION TO IMPROVE MEDICAL SERVICE (USING GOOGLE MAPS)
}

\author{
Enayat Ali \\ Dept. of Information Systems \\ College Art and Science \\ King Khalid University \\ Abha, Saudi Arabia
}

\author{
Dr. Osman A. Nasr \\ Dept. of Management Information System \\ College of Computer Science and Information Technology, \\ Neelain University \\ King Khalid University Abha, Saudi Arabia
}

\author{
Dr. Eltyeb E.Abed Elgabar \\ College of Computer Science and Information Technology \\ Dept. of Computer Science \\ Neelain University \\ Khartoum, Sudan
}

\begin{abstract}
Since medical services are the most vital needs for people, providing appropriate facilities to patients remains an important issue for deciders. To upgrade health services and using the System Development Life Cycle methodology, a system that helps residences in clinics or hospitals managing appointments, communicating and using GPS services is set up. This system is aiming to enhance the performances of medical institutions and users' satisfaction when doing their tasks.
\end{abstract}

Keywords: Google MAPS, Global Positioning System, Medical Service, Mobile Application

\section{INTRODUCTION}

The improvement of health care facilities must be given a lot of consideration. Those facilities should allow people to find the nearest center and to check their records and appointments. It must provide customized services with respect to patients' needs and requirements. On this basis, this research suggests a system that enables hospitals and other health services to display and to make easily available their medical staff and all services towards patients.

\section{PROBLEM DESCRIPTION AND SOLUTION PROPOSITION}

In view of the need of patients for fast, accurate et customized health services, and regarding health centers' inability to respond to such needs through existing systems, this research aims to provide a solution that permits to patients the following:

To find quickly and easily the nearest and best center that provides services in accordance with their needs especially for emergencies.

To compare between services that are provided by different health centers and to choose the one that meet their needs.

To directly communicate with doctors and medical staff without personal attendance to gain effort and time for all parts.

To make appointments and track and comfortably keep track of records.

This solution also permits to health centers to display towards people their functionalities, specialties, staffs and levels of services. Using different techniques such as GPS and central data recording, the proposed system is applicable for all kinds of centers. In Table 1, we show what this system proposes in terms of services and facilities compared to existing systems.

\section{EXISTING VS. PROPOSED SYSTEMS}

Table 1: EXISTING VS. PROPOSED SYSTEMS

\begin{tabular}{|c|c|c|}
\hline Services & $\begin{array}{l}\text { Existing } \\
\text { Systems }\end{array}$ & $\begin{array}{l}\text { Proposed } \\
\text { System }\end{array}$ \\
\hline $\begin{array}{l}\text { Appointment } \\
\text { reservation/check } \\
\text { tests results/ask } \\
\text { question to doctors }\end{array}$ & $\begin{array}{l}\text { Need patient } \\
\text { personal } \\
\text { attendance. }\end{array}$ & $\begin{array}{l}\text { Remotely through } \\
\text { the application } \\
\text { and the internet. }\end{array}$ \\
\hline $\begin{array}{l}\text { Waiting time for } \\
\text { receiving medical } \\
\text { services }\end{array}$ & long periods & $\begin{array}{l}\text { Minimum period } \\
\text { of time }\end{array}$ \\
\hline $\begin{array}{l}\text { Patient medical } \\
\text { record display }\end{array}$ & $\begin{array}{l}\text { Unless the } \\
\text { patient visits the } \\
\text { medical center }\end{array}$ & $\begin{array}{l}\text { viewed and } \\
\text { updated online } \\
\text { without the need } \\
\text { for patient' visit }\end{array}$ \\
\hline $\begin{array}{l}\text { Information } \\
\text { introduced by } \\
\text { Medical Centers }\end{array}$ & $\begin{array}{l}\text { Hardly spread } \\
\text { and deployed } \\
\text { among people }\end{array}$ & $\begin{array}{l}\text { a single } \\
\text { centralized online } \\
\text { place to display } \\
\text { information }\end{array}$ \\
\hline $\begin{array}{lr}\text { Finding } & \text { the most } \\
\text { suitable } & \text { medical } \\
\text { center }\end{array}$ & $\begin{array}{l}\text { Needs the actual } \\
\text { visit of the } \\
\text { patient to } \\
\text { compare } \\
\text { between centers }\end{array}$ & $\begin{array}{l}\text { Online } \\
\text { mechanisms to } \\
\text { compare between } \\
\text { centers' services }\end{array}$ \\
\hline $\begin{array}{lr}\text { Sharing } & \text { medical } \\
\text { information } & \text { and }\end{array}$ & $\begin{array}{l}\text { hard to spread } \\
\text { especially in }\end{array}$ & $\begin{array}{l}\text { Easily shared and } \\
\text { deployed online }\end{array}$ \\
\hline
\end{tabular}




\begin{tabular}{|l|l|l|}
\hline instructions & $\begin{array}{l}\text { specific } \\
\text { situations }\end{array}$ & \\
\hline
\end{tabular}

\section{SDLC (SOFTWARE DEVELOPMENT LIFE CYCLE) APPLIED}

There are seven phases within SDLC:

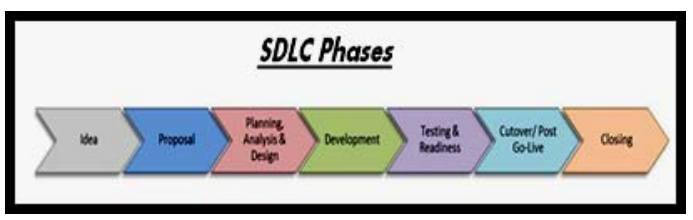

Figure 1: SDLC Phases

a. Idea Phase:

Short evaluation of request to determine If resources should be expended to pursue, and If it is actually a project, versus an operational request.

b. Proposal Phase:

Detailed business case, solution description and comparison of alternatives. includes business requirements, estimated resource requirements and funding requirements.

c. Planning, Analysis \& Design Phase:

Charter approval, project kickoff, schedule development, project planning.[1]

d. Development Phase:

Begin solution/change development, and plan for testing, readiness and deployment.

e. Testing \& Readiness:

Test solution/changes in controlled environment. Begin readiness activities for go live of solution. Go live. [2]

f. Cut over/Post Go Live:

Monitor implementation of the solution/changes for a predetermined period.

g. Closing:

Lessons learned. Formally transition the solution/changes to permanent owner. Release project team. [3]

\section{ANALYSIS PROCESS DIAGRAMS:}

To illustrate the analysis process diagrams, UML is used, The Unified Modeling Language (UML) is a standard visual modeling language intended to be used for:

- Modeling business and similar processes.

- Analysis, design, and implementation of software based systems.[4]

\subsection{Use Case Diagrams:}

describes the process by which users can create a personal account to log into the application, and enable to which users can search for a medical center upon the option they prefer[5], and reserve a new appointment, edit or cancel a pre-reserved one, in addition This Use Case describes the process by which users and doctors can query and view their appointments, and users 'patient' can edit and update their communication information saved in their records, the below Use Case also describes the process by which users and patients can ask questions to their doctors, and the doctors answer them, then the questions and answers can be displayed for other users.

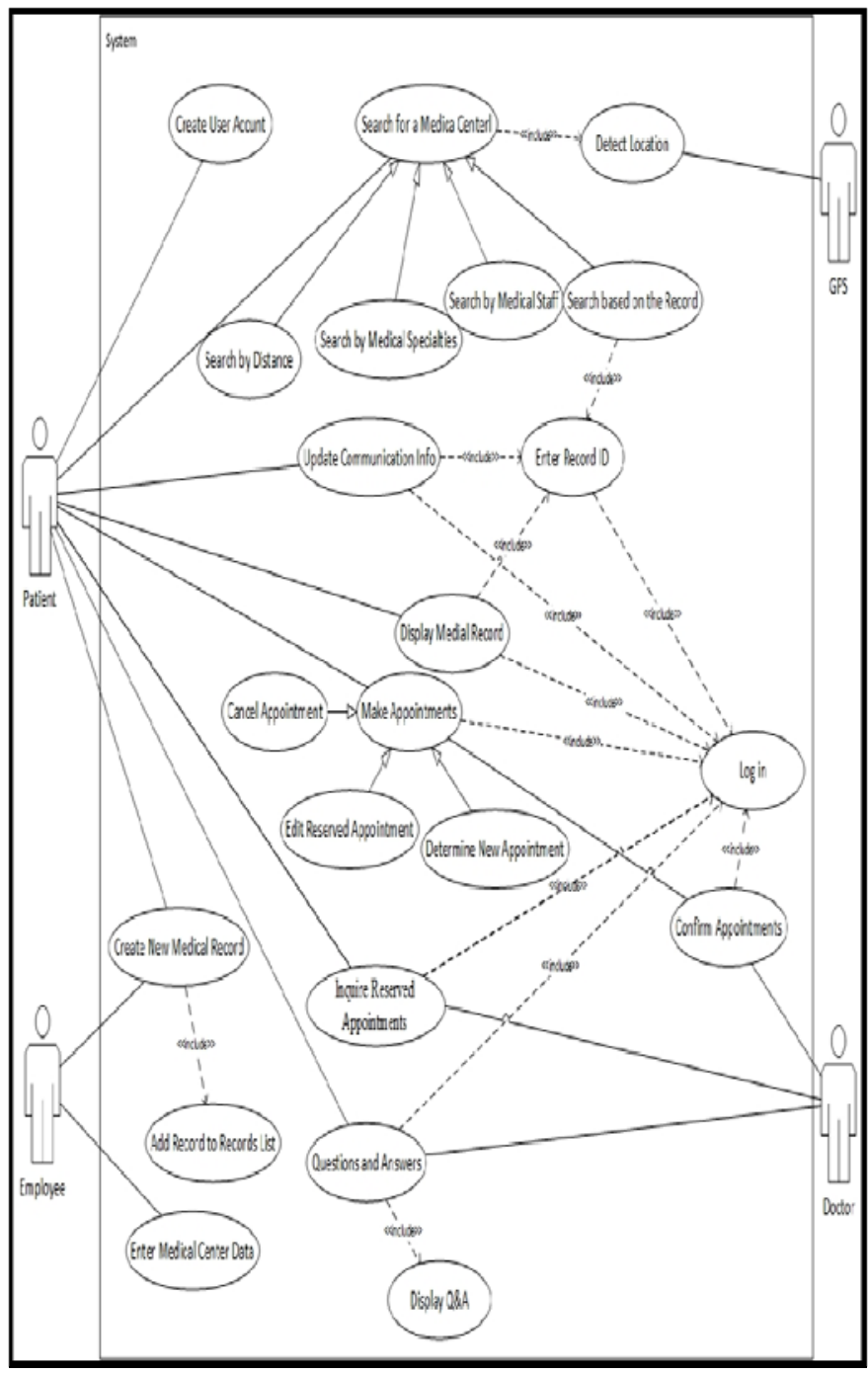

Figure 2 : System Use Case Diagram

\subsection{Sequence Diagrams:}

Sequence diagram describes an interaction by focusing on the sequence of messages that are exchanged [6], along with their corresponding occurrence specifications on the lifelines.[7]

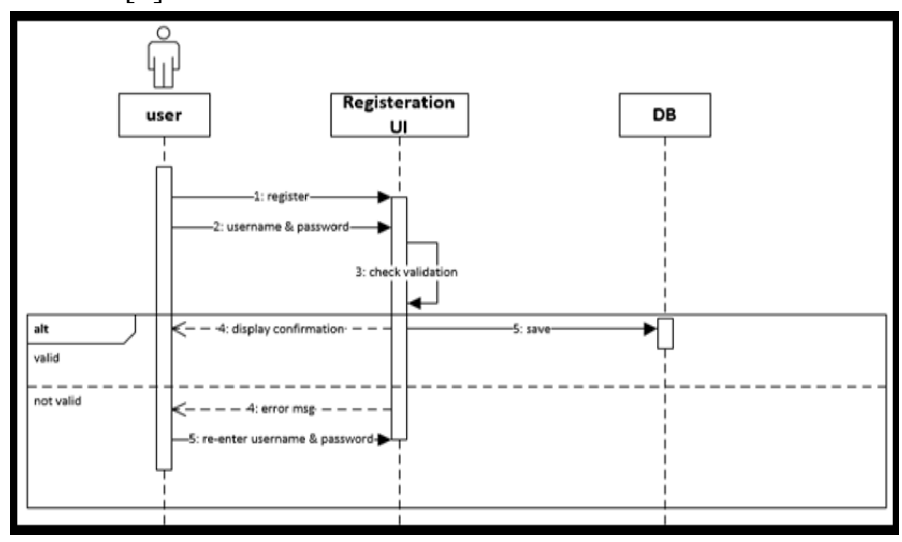

Figure 3 - SD-01 


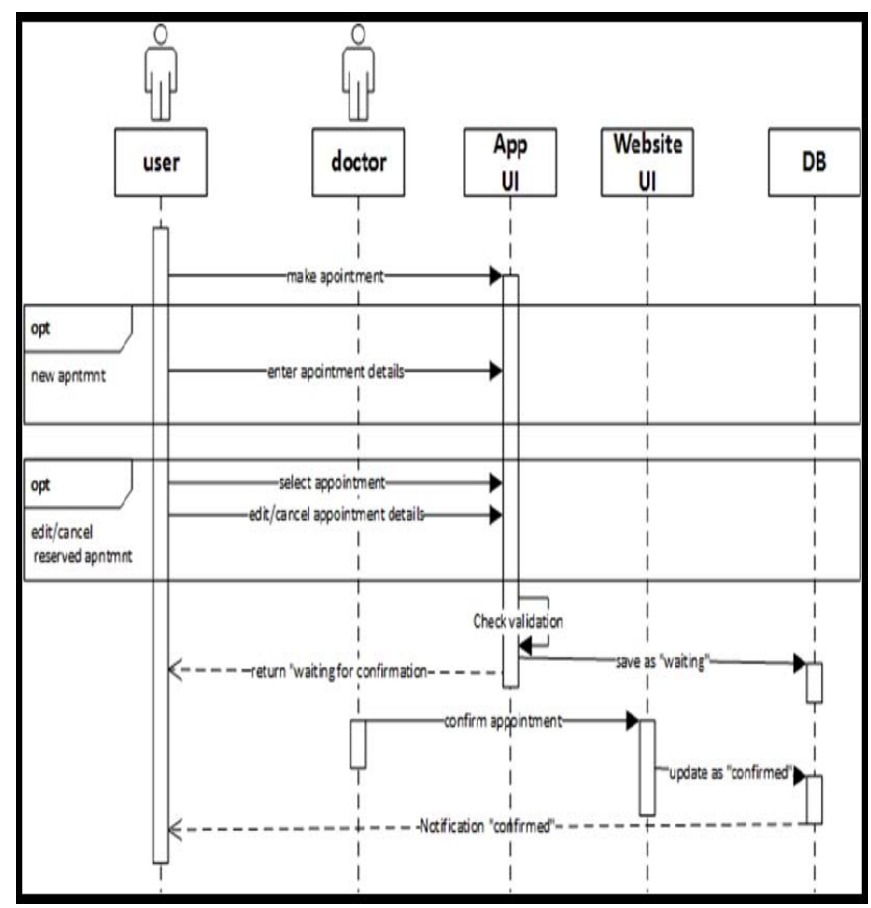

Figure 4: SD-02

\subsection{ERD (Entity Relationship Diagram):}

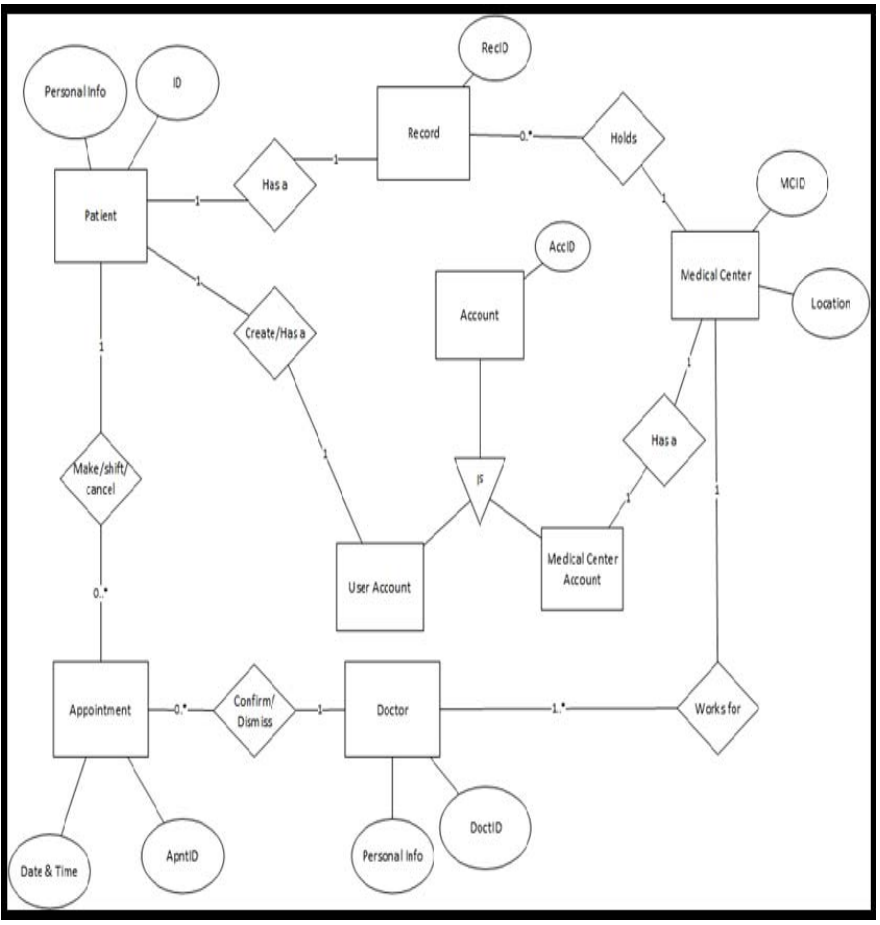

Figure 5: ERD

\subsection{Database Tables Design:}

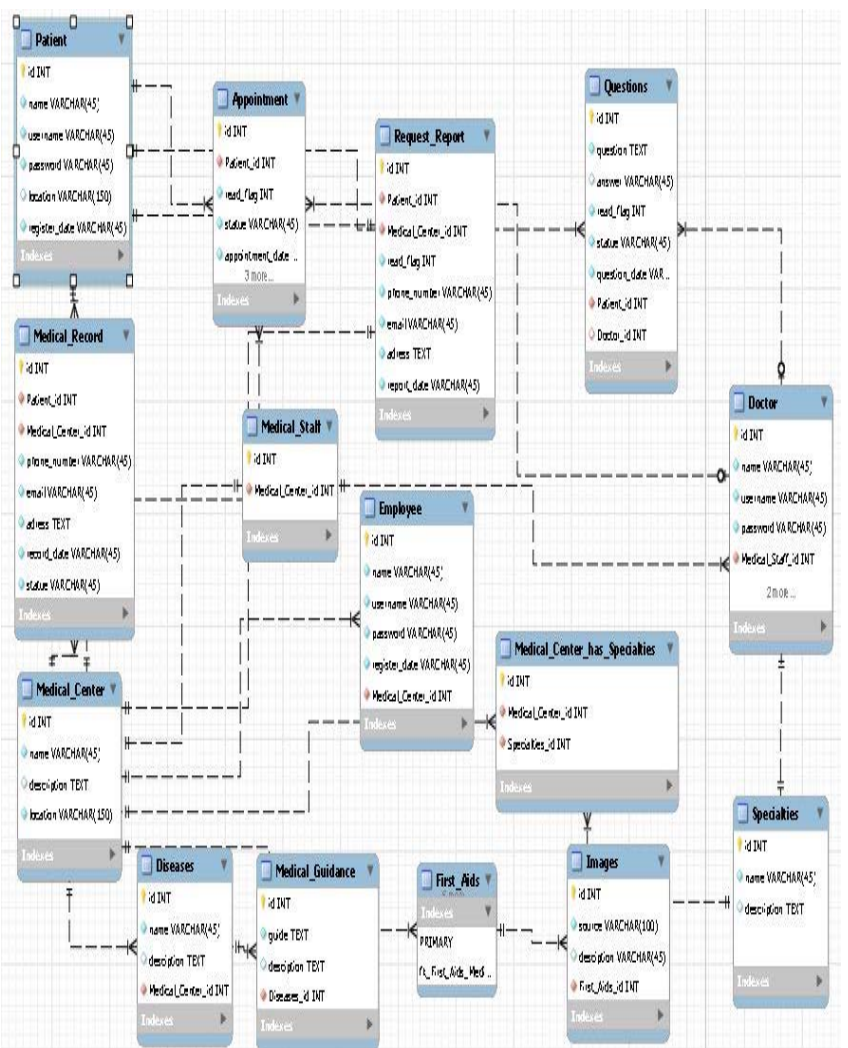

Figure 6: Database Tables Design

\subsection{User Interfaces Design}

\subsubsection{Sign up/Log in Interface}

Description: When the user starts the application he should see this interface which enables him to Log in or to sign up to a new account.
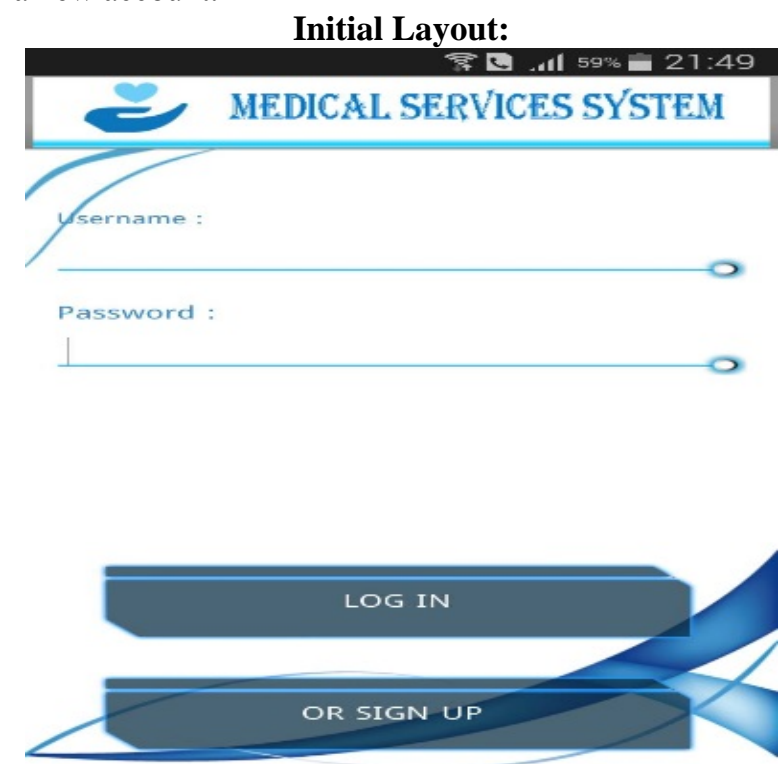

Figure 7: Sign Up/Login Interface

\subsubsection{Search Interface}

Description: the search interface provides the user the ability to choose the type of search he wants to conduct, then perform it to find the medical centers. 


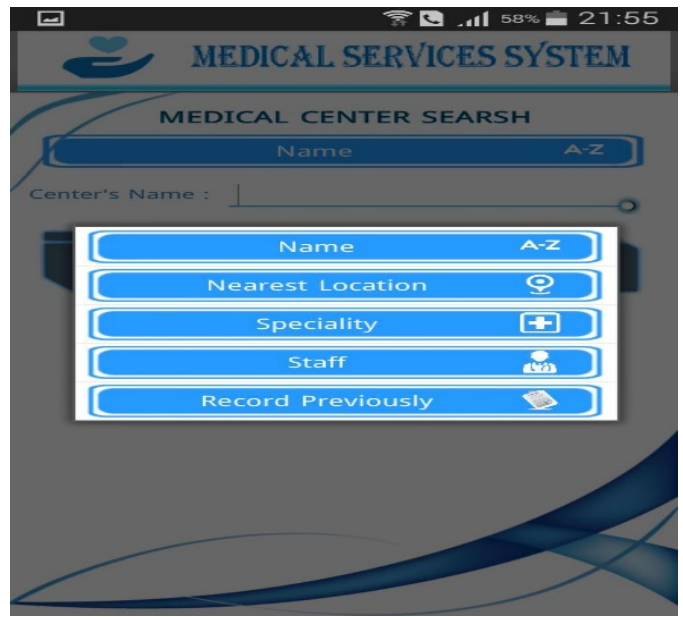

Figure 8: Search Interface

\subsubsection{Appointments Interface}

Description: this interface enables the user to reserve an appointment, query for pre-reserved appointments and display external clinics times.
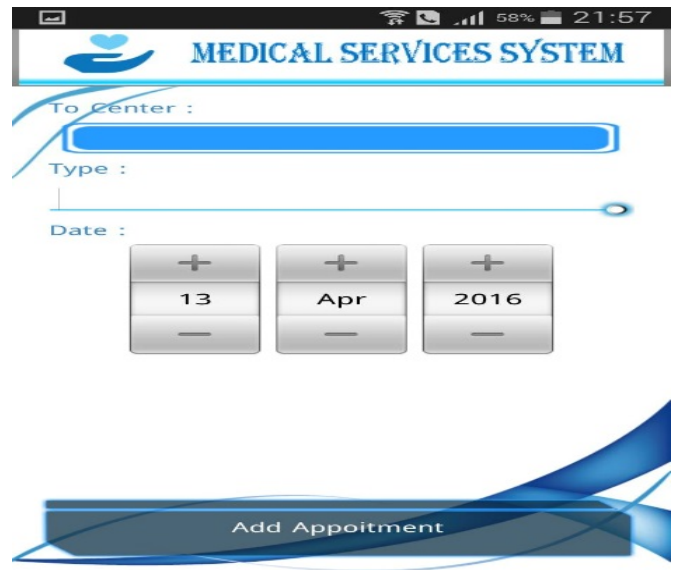

Figure 9: Appointment Interface

\subsubsection{Settings and Updates Account Data Interface}

Description: this interface is for enabling users (patients) from updating their account data (Name, user name and password)

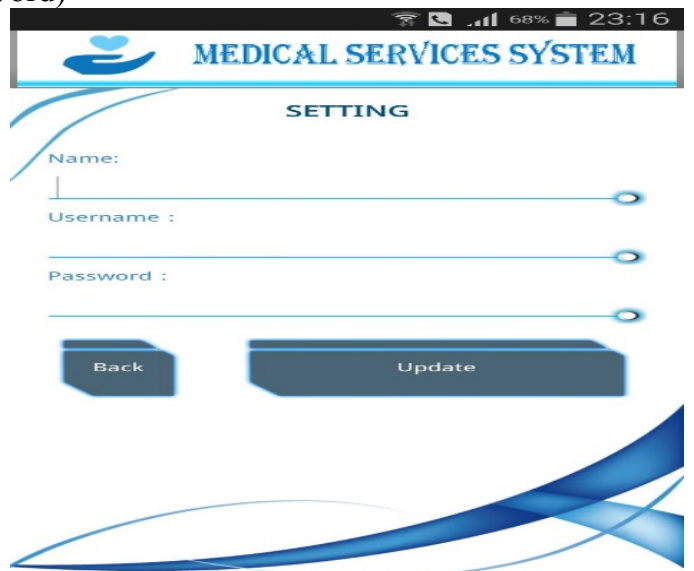

Figure 10: Settings and Updates Account Data Interface

\subsubsection{New Account Interface}

Description: users can create a new account with this interface; enter the new username, password and email address or mobile phone number.
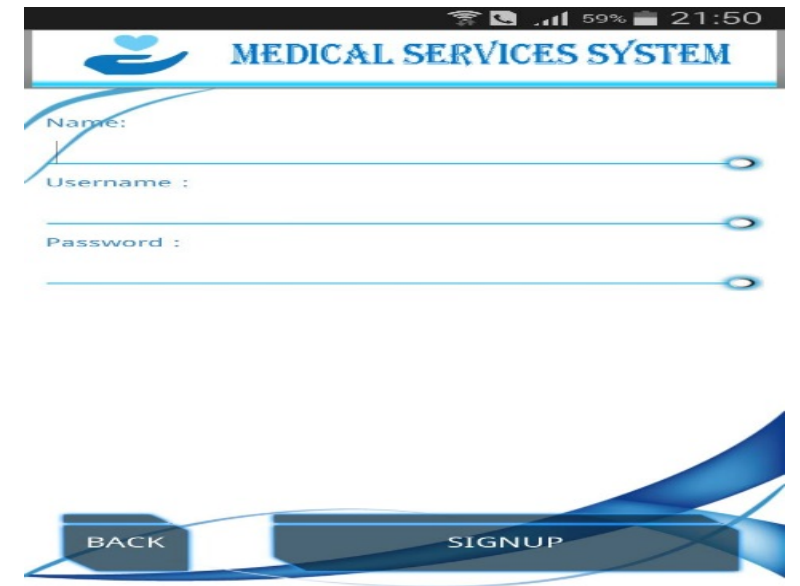

Figure 11: New Account Interface

\subsubsection{Medical Guide:}

Description: this interface is dedicated for patients medical learning such as medical instructions deployed by Medical Centers as well as special cases and situations handling details.
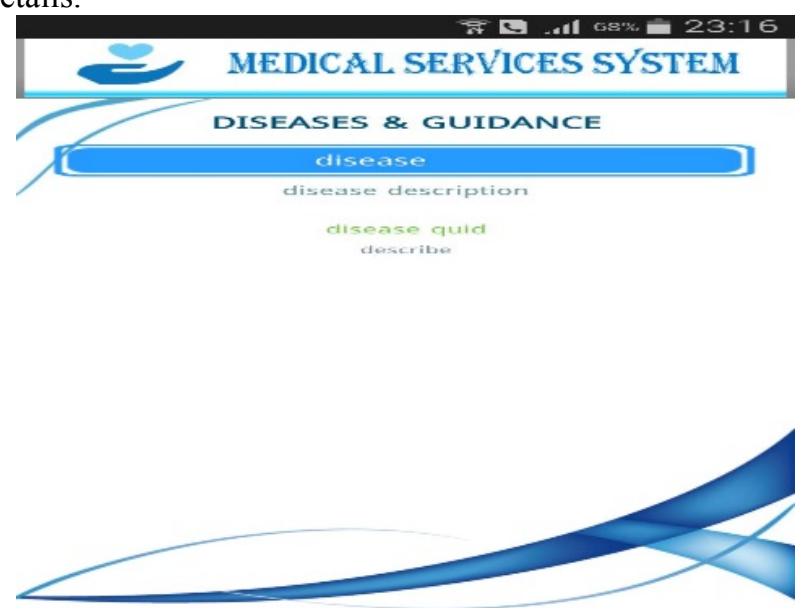

Figure 12: Medical Guide Interface

\section{RESULTS AND CONCLUSION}

It is anticipated that this application will present appropriate and desirable services to most users in areas where it is applied. This will be made based on the surveys that have been made and published in order to recognize residences opinions about their willing to use such an application. Results show that more than $95 \%$ of those have expressed that such application will be useful as it is important to serve patients during special cases. Again, more than 50\% have said that this application will be so important in case of critical emergencies.

Therefore, we can see that the availability of this proposed software application will be desirable to the residences of the target area, as it will provide positive results to those benefiting sides from this application.

\section{OTHER RECOMMENDATIONS}

For future plans there can be a lot of additional ideas and options to be added to the application such as the ability of a user (medical staff member or a patient) to self-enrollment and participate in some medical courses or tutorials by the application. Another option is that a user can search for pharmacies and purchase of medicines an online. 


\section{REFERENCES}

[1] Kevin Roebuck, Systems Development Life Cycle (SDLC), one Edition, 2011, Tebbo, Australia, pp 150-200.

[2] R. Stair, W. Reynolds, Principles of Information Systems: A Managerial Approach, Ninth Edition, 2010, Course Technology, Boston, United States of America, pp 506-523.

[3] A.Dennis, Barbara H.Wixom, Roberta M.Roth, Systems Analysis \& Design ,Fifth Edition , 2012, John Wiley \& Sons , United States of America, pp 147-180.
[4] Brett D. McLaughlin, Gary Pollice, David West, Object Oriented Analysis \& Design, First Edition, 2007, O'Reilly Media, United States of America, pp 159-221.

[5] Gary B.Shelly, Harry J.RosenBlatt, Systems Analysis And Design, Eighth Edition, 2010, Course Technology, Boston, United States of America, pp 147-264.

[6] Turban, E. Ephrain, and J. Wetherbe, Information Technology for Management, Fifth Edition, 2005, John Willey \& Sons, Inc. , New York.

[7] Kenneth E. Kendall, Julie E.Kendall, Systems Analysis and Design Eighth Edition, 2011, Prentice-Hall, pp 29-52. 